\title{
MODELS IN INFORMATION SYSTEMS DEVELOPMENT
}

\section{Anna EXNAROVÁ}

\begin{abstract}
The models and the modeling have the irreplaceable role in the process of information systems development. Sophistication of the modeling techniques, methodologies and the complexity of modeling tools allow to create complex models. The main purpose of this paper is to provide the proposed classification of models (and set up a framework for discussion about the modeling). The approach is based on the author's efforts to accent the systemic view of issues compared with traditional concept of "technical" modeling and provides a framework for discussing the modeling of both practical and theoretical level.
\end{abstract}

Key words: model, model of information system, standardized models, software tool for modeling, language of model, methodology of modeling, characteristics of model.

\section{MODELY VE VÝVOJI INFORMATČNÍCH SYSTÉMŮ}

Resumé: V procesu vývoje informačního systému má modelování a tvorba modelů nezastupitelnou úlohu. Propracovanost modelovacích technik, metodik a komplexnost modelovacích nástrojů umožňují vytvářet složité modely informačních systémů. Cílem článku je představení pohledu na modelování SW a návrh na klasifikaci modelů v informatice. Př́nos navrženého členění lze spatřovat ve zdůraznění existence dvou skupin modelů a jejich charakteristik, které umožní lepší uchopení a uplatnění těchto modelů. Př́istup autorky vychází ze snahy o akcent systémového pohledu na problematiku modelování SW oproti tradičnímu „technickému“ pojetí a poskytuje rámec pro diskusi o modelování jak v praktické, tak teoretické rovině.

Klíčová slova: model, model informačního systému, standardizované modely, modelovací nástroj, modelovací jazyk, metodika modelování, vlastnosti modelu.

Tento článek byl zpracován za podpory prostředků institucionální podpory na dlouhodobý koncepční rozvoj vědy a výzkumu na Fakultě informatiky a statistiky VŠE v Praze, projekt ,,VŠE IP400040“.

\section{1 Úvod}

Modelování je soubor činností, které vedou $\mathrm{k}$ vyjádření různých pohledů na vybraný systém standardizovanými, př́p. formalizovanými prostředky. Z obecného pohledu Křemen říká, že model je ve své podstatě jazykovým útvarem, který slouží jako komunikace-schopný záznam rozpracovanosti. Tedy dokumentuje to co bylo vytvořeno a co se očekává, že vytvořeno bude. [Křemen, 2007] Jedním z hlavních principů analytické fáze vývoje informačních systémů je právě modelování. Umožňuje vytvořit specifický abstraktní pohled na charakteristiky budoucího informačního systému. Často opakovanými vlastnostmi těchto systémů jsou složitost, rozsáhlost, komplexnost. Modelování umožňuje „oddělit“ jednotlivé vlastnosti a vrstvy vyvíjeného systému, přesáhnout hranice mentálních modelů a podpořit vytvoření systému požadovaných kvalit.

S oblastí informačních technologií se spojuje celá řada typů modelů: modely sítové infrastruktury, modely tříúrovňové architektury systému, modely komunikace zákazníka se systémem, organizační modely, modely dopadů ekonomických faktorů na řízení informatiky, a také modely konkrétní aplikací. Modelovat lze různé části informačního systému, $\mathrm{v}$ různé granularitě, vizuálně lze znázornit realitu minulou, současnou nebo budoucí. Pojem model je v dalším textu ztotožňován $\mathrm{s}$ reprezentací a vizualizací vyvíjeného informačního systému (také IS).

Odborná literatura věnovala $\mathrm{v}$ minulosti rozsáhlou pozornost modelování a tvorba modelů byla jednou $\mathrm{z}$ diskutovaných činností v analytické fázi vývoje IS. Odborná diskuse, zainteresovanost praxe i vědecké veřejnosti, podpora institucí i velkých korporací a softwarových firem byla dobrou základnou pro vytvoření poměrně dobře propracovaných metodik, technik i notací modelování. Na poli modelování dnes existují principy a techniky, 
které lze označovat za obecně velmi dobře známé, část $\mathrm{z}$ nich je již v pozici standardů.

Nicméně metodiky, striktní notace a přesná pravidla modelování, i pevně ukotvený životní cyklus modelů v metodice vývoje SW, jsou častokrát velmi omezující a v praxi je nutné použít „volnější prístup. Vedle tradičních, standardizovaných modelů se lze setkat s modely vytvořenými „na míru“, tzv. „fun“ modely.

Volba, který model je reálně použit a jaký proces je s ním spojen, se odvíjí od zodpovězení celé řady otázek a uvědomění si mnoha souvislostí. Některé z nich nastiňuje následující kapitola.

\section{2 Životní cyklus modelů}

Na svět nahlížíme přes naše mentální modely, které jsou velice individuální, obsahují ze své podstaty chyby a samostatně použité poskytují nevyhovující výsledky při řešení složitých problémů. Systémové myšlení pomáhá měnit mentální modely. Představuje soubor metod, př́stupů, modelů, které po úspěšném zvládnutí poskytují velkou výhodu - schopnost lépe řešit problémy, přizpůsobovat se změnám okolí a chápat podstatu světa. Systémové myšlení je uměním a vědou o tom, jak formulovat spolehlivé závěry o chování systému, a to na základě hlubokého pochopení jeho struktury. „Běžné analytické myšlení ignoruje dynamiku a variabilitu.“ [Mildeová, 2007, str. 8]

Lidské mentální modely jsou komplexní a multidimensionální směsicí obrazů a zkušeností, a poměrně důsledně odrážejí osvojený způsob myšlení. Od dětství máme naučené postupy rozdělit problém na menší části a řešit samostatné fragmenty. Je to postup, který nám zdánlivě „ulehčí'“ řešení složitých úloh. Daň, kterou za to musíme platit, je nemožnost vidět důsledky a ztráta smyslu pro souvislosti s větším celkem. Pokud chceme vidět celý obraz, musíme se pokusit znovu poskládat jednotlivé kousky do celku včetně jejich souvislostí. (převzato ze [Senge, 1995]). Jedna $\mathrm{z}$ cest, jak odstranit prirozené hranice mentálních modelů je tvorba a použivání modelů. Tento proces (životní cyklus modelu) lze shrnout do sedmi základních kroků.

1. Vyjasnění, $\mathrm{k}$ čemu model bude používán, jaký je cíl jeho existence.

2. Analýza reálné situace $(\mathrm{z}$ pohledu systému i z pohledu dostupných nástrojů, znalostí tvůrců, schopností budoucích uživatelů).

3. Tvorba / výběr metodiky modelu jazykové prostředky, nástroje a metodiky.
4. Sběr informací, které jsou nezbytné pro vytvoření modelu ( $\mathrm{v}$ druhém kroku byla provedena analýza, na základě které byla zvolena metodika - díky ní se lze vrátit zpět a získat všechny potřebné informace).

5. Tvorba samotného modelu.

6. Využívání modelu uživateli.

7. Aktualizace modelu (př́íp. odstranění).

Klíčovým bodem je krok 1 - definování cíle existence modelu je nesmírně důležité proto, aby bylo možné zvolit správný typ modelu, konkrétní postup jeho tvorby a celý jeho životní cyklus (s ohledem na náklady a prínosy, které samozřejmě každý model provází). Existence modelu může být definována velmi odlišně.

Model je explicitním vyjádřením našich predstav, zachycuje vybrané aspekty systému. Je reflexí reálných situací nebo představ. Obecně lze rríci, že model může sloužit k:

- formulaci hypotéz,

- záznam vybraných charakteristik reality,

- dokumentaci současného stavu,

- zachycení změn v systému,

- simulaci chování systému.

Důvodem existence modelu tedy může být snaha o získání informací o stavu projektu, potřeba komunikace informací jak uvnitř týmu, tak vůči zákazníkovi, dokumentace systému, zobrazení uspořádání prvků, potřeba provádění simulací a experimentů, nutnost vytvořit prototypy, snaha o automatizaci výstupů, potřeba o odstínění od zavádějících informací.

Každý krok životního cyklu modelu by měl být ovlivněn odpověd'mi na otázky:

- Proč model vzniká - jaký je důvod jeho existence.

- Jaký systém zobrazuje, jakou realitu představuje.

- Kdo ho vytváŕí, s jakými nástroji a znalostmi

- Kdo ho bude používat, s jakými nástroji a znalostmi.

- Jak často se bude aktualizovat, jaká je periodicita změn a jejich objem.

$\mathrm{Na}$ základě těchto otázek (potažmo odpovědní) byly navrženy dvě skupiny modelů: modely standardizované a modely nestandardizované.

Rozdělení modelů do těchto dvou velkých skupin považuji za významné. V podnikové praxi jsou obě tyto skupiny nezastupitelné, i když především ve firmách více technicky orientovaných se setkáváme $\mathrm{s}$ podceňováním skupiny nestandardizovaných modelů. Přínosy tohoto dělení modelů jsou: 
- Zdůraznění (často opomíjené) existence nestandardizovaných modelů.

- Definované charakteristiky jasně deklarují vlastnosti modelu - zvolením konkrétního typu modelu musíme akceptovat jeho vlastnosti. Díky jasné definici by nemělo docházet $\mathrm{k}$ rozčarování př̀i implementaci daného typu modelu v reálné situaci.

- V prvních krocích životního cyklu modelu může toto dělení poskytnout pomoc při rozhodování o výběru konkrétního typu modelu.

- Pro práci s modely a analýzu dané oblasti je př́nosem existující klasifikace s deklarovanými vlastnostmi, které by při celistvém pohledu bez kategorizace nemusely být identifikovány.

\section{Standardizované modely}

Standardizované modely jsou modely, které mají poměrně pevně definovanou metodiku, která je vyvíjena $v$ dlouhém období za spoluúčasti významných organizací a institucí a jejichž použití se významně rozš́iríilo do praxe. O těchto modelech lze rríci, že jsou obecně „well-known“ velmi dobře známé. Velkou výhodou je jejich obecné použití - díky obecné znalosti je model srozumitelný v širokém okruhu tvůrců i uživatelů (většinou z okruhu IT).

Mezi standardizované modely můžeme řadit celou škálu modelů - od samožrejmě přijímaných modelů UML (Unified Modeling Language), DFD (data flow diagram), BPMN (business process modeling notation), E-R diagramy, EPC až ke Ganttovým diagramům a systémovědynamickým modelům. Všechny tyto modely mají svojí notaci vizualizace informací, a pomocí všech těchto modelů můžeme modelovat určitou část informačního systému.

Při používání standardizovaných modelů je nutno akcentovat jejich základní vlastnosti. Mnohé problémy praxe, kdy standardizovaný model nesplní očekávání, jsou spojeny právě s nízkou akceptací vlastností těchto modelů a tedy i limity, které tyto modely mají.

Standardizované modely v rámci své definice mají více či méně specifikovaný účel existence např. BPMN jsou určeny pro modelování procesů. Definování účelu je spojeno s vymezením části reality, která je modelována. Ve většině případů nelze u standardizovaných modelů měnit jejich primární účel nebo realitu, kterou by měly zobrazovat.

Tvůrcem a zároveň př́ijemcem většiny standardizovaných modelů jsou odborníci, většinou analytici, architekti, designéři i programátoři. $\mathrm{V}$ některých př́ípadech nad modelem pracuje také zákazník - bud' $\mathrm{v}$ analytické části projektu, nebo $\mathrm{v}$ rámci práce s dokumentací. Díky poměrně přesně definované podobě jsou uplatnitelné $i$ ve firmách i při komunikaci se zákazníkem. Na tvůrce i uživatele ale kladou požadavek na znalost jazykové struktury a schopnost aplikovat tuto obecnou znalost na konkrétní situaci.

Všeobecně známá standardizovaná jazyková struktura modelu je poměrně dobrým předpokladem pro jeho obecné používání. $\mathrm{K}$ rozšířenosti modelů ve velké míře přispívá také podpora softwarových nástrojů, které umožňují daný typ modelů vytvářet, nebo dokonce podpořit celý životní cyklus modelu. Pokud se jedná o komerční nástroje, jsou většinou na vysoké úrovni propracovanosti a obsahují velké množství dalších funkcionalit (např̀ automatické generování dokumentace, generování kódu, verzování, podpora fáze designu a programování, atd.).

Je vhodné si uvědomit, že většina modelů je tvořena $\mathrm{v}$ softwarovém nástroji, který do velké míry diktuje a upravuje obecné charakteristiky a definuje vlastní metodiku použití modelu v konkrétních krocích návrhu. Proto v mnohých prŕípadech musí vznikat vedle obecných metodik také detailní metodické postupy - tyto detailní postupy obsahují navíc aplikaci obecných modelovacích postupů $\mathrm{v}$ daném nástroji ve vazbě na konkrétní situaci a modelovaný systém. Tak se i $\mathrm{v}$ běžné praxi setkáváme $\mathrm{s}$ přechodem od obecných standardizovaných modelů $\mathrm{k}$ instanci konkrétního modelu a někdy až $\mathrm{k}$ vytvoření individuálních nestandardizovaných modelů.

$\mathrm{V}$ některých případech je situace opačná nástroj nás omezuje $\mathrm{v}$ modelování reality nad rámec UML, výsledný model je „ochuzený“ o informace, které by dle metodiky UML měly být umožněny. $\mathrm{S}$ touto situací se musí vyrovnat jak tvưrce, tak uživatel, a je velmi podstatné si tento rozdíl uvědomit.

S rostoucí oblibou a možnostmi modelovacích jazyků roste samozřejmě i jejich rozsáhlost, komplexnost i komplikovanost. Tvorba a práce $\mathrm{s}$ těmito modely se tak stává odbornou záležitostí. Požadavkem je znalost a schopnost skloubení jak obecné metodiky, tak možností modelovacího nástroje a konkrétních vlastností IS.

Výše uvedené a komentované charakteristiky standardizovaných modelů jsou schematicky uvedeny Obr. 1 - Atributy nestandardizovaného modelu. 


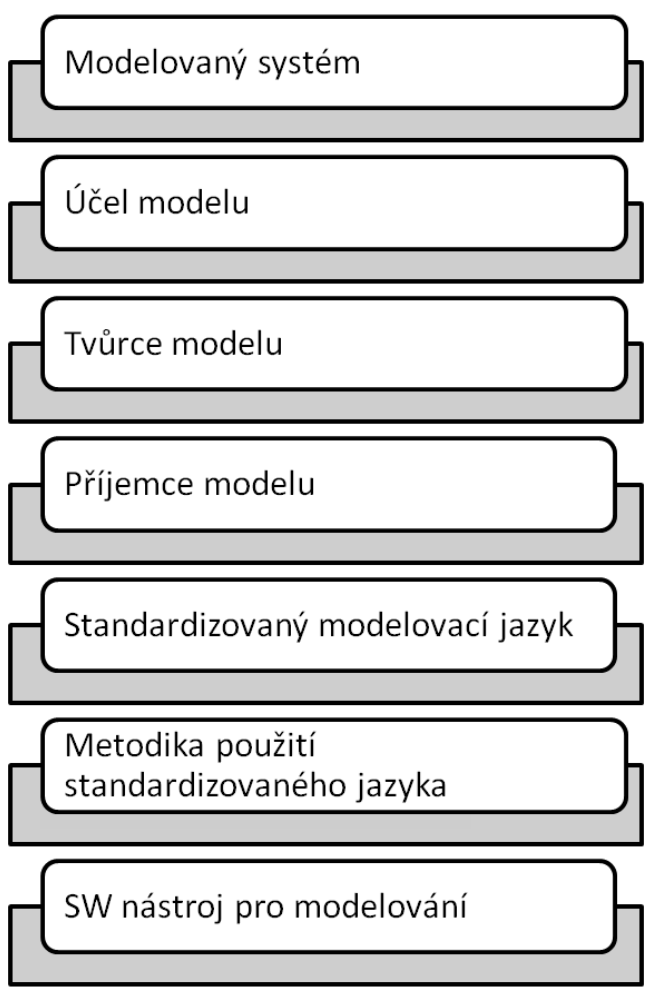

Obr. 1 - Atributy standardizovaného modelu

\section{Nestandardizované modely}

Praxe často přináší složité situace, ve kterých model je možným způsobem řešení - napřn. zákazníkovi je potřebné představit budovaný informační systém a zdůraznit vybrané charakteristiky, kterých si musí být vědom. Klíčovým bodem je volba správné formy komunikace složitých a rozsáhlých informací. Vizualizace informací formou modelů bývá jednou z obecně rozšsiřených variant.

Účelem nestandardizovaných modelů je poskytnout možnost, jak sdělit informace specifickou formou v konkrétní situaci s přesně cílenou vizualizací pro daného zákazníka. Většina nestandardizovaných modelů je tvořena s cílem rychlého a jednoduchého sdělení informací.

Nestandardizované modely nemají definované obecné jazykové výrazové prostřredky, nejsou univerzálně použitelné, jejich tvưrci musí postavit celou strukturu modelu a liší se prŕpad od př́padu. $\mathrm{V}$ praxi se pro tyto modely někdy užívá označení „fun diagramy“ nebo „manažerské modely“.

Tyto modely jsou naproti výše uvedeným standardizovaným modelům určeny především pro uživatele, kteř́ nemají potřebný technický a metodický základ znalostí. Mohou být proto určeny širšímu okruhu príijemců, nebo příjemcům s odlišnou bází znalostí a zkušeností (např. zákazníkovi, manažerům, účetním). Znázorněné informace modelovaného systému na druhou stranu nemohou mít stejnou míru detailu jako standardizované modely. Jejich výhoda je v jednoduchém a přehledném zobrazení informací. Na uživatele neklade skoro žádné nároky. Tyto modely jsou většinou používané pro zákazníka ze skupiny „ne IT“, pro manažerské rozhodování, nebo pro rychlou orientaci v systému.

Naproti tomu pro tvůrce je tvorba poměrně složitou záležitostí - neexistuje konkrétní jazyk ani metodika, kterou by bylo možno použít. (Samozřejmě, že tyto modely mohou být tvořeny na základě již existujících standardizovaných modelů, nicméně jejich výsledná podoba a použití je natolik rozdílné, že již nelze mluvit o instanci daného modelu.) Všechny takto vytvořené modely se musí vytvářet na míru uživateli a systému. Tvůrce většinou vychází z již existujícího standardizovaného jazyka, který je ale výrazně upravován a na základě kterého je vytvářen nový jazyk. Tento proces bývá do značné míry ovlivněn konvencemi, které jsou ve firmě zaužívané, ale také schopností a kreativitou tvưrce. Proces stabilizace nového jazyka je poměrně dlouhý a je také výrazně ovlivněn nástrojem, který je pro daný model vybrán, a který staví mantinely jak $\mathrm{v}$ definici jazyka, tak $\mathrm{v}$ metodice. Výběr softwarového nástroje pro modelování omezuje a určuje základní modelovací prvky jazyka, které tvưrce musí definovat a určit jejich význam a použití v nově tvořeném modelu.

Nástroj většinou musí splňovat požadavky na grafickou úpravu a výsledný design, proto je ve většině př́padů nutné volit nástroje typu MS Visio, kde lze skloubit základní nástroje pro tvorbu diagramů, nicméně lze je $\mathrm{v}$ široké paletě nástrojů graficky modifikovat.

Při tvorbě těchto modelů můžeme použivat celou řadu SW nástrojů, které jsou určené přímo pro tvorbu různých typů standardizovaných modelů. Pokud se jedná o komerční nástroje, jsou většinou na vysoké úrovni propracovanosti a obsahují velké množství dalších funkcionalit. Jednou $\mathrm{z}$ nich je možnost generování dokumentace (žádný model není úplný bez dokumentace).

$\mathrm{V}$ př́ípadě tvorby nestandardizovaných modelů $\mathrm{v}$ nástrojích typu MS Visio, nebo dokonce grafických nástrojích, je tvorba modelu rozdílná - nástroje umožňují vytvořit dokonalejší grafickou stránku modelu (což pro nestandardizované modely je jedno z hlavních 
kritérií), nicméně neobsahují žádné další nadstavby a $\mathrm{v}$ př́padě dokumentace je nutno tvořit ji ručně. $\mathrm{V}$ současné době jsou však již i běžné nástroje pro tvorbu modelů natolik propracované, že grafické výstupy $\mathrm{z}$ těchto nástrojů začínají být plně dostačující.

Aktuálnost modelu je jedním $\mathrm{z}$ hlavních požadavků, který na již vytvořený model, mají uživatelé. Snadnost aktualizace dat je do velké míry ovlivněna opět výběrem konkrétního nástroje. Lze konstatovat, že i $\mathrm{v}$ tomto př́padě standardní modelovací nástroje poskytují propracovanější možnosti správy a aktualizace jednotlivých elementů (správa elementů v rámci centrálního úložišstě a následné využívání těchto elementů $\mathrm{v}$ různých diagramech snižuje náročnost aktualizace).

Nestandardizované modely obsahují méně informací, ale většina těchto informací by měla být velmi lehce zjistitelná (obvykle na první pohled). Díky této vlastnosti jsou nestandardizované modely velmi lehce převoditelné do podoby obrázků (u standardních modelů se $\mathrm{z}$ pouhého obrázku $\mathrm{v}$ porovnání s modelem dozvíme pouze velmi omezený okruh informací).

Výše uvedené charakteristiky nestandardizovaných modelů jsou schematicky uvedeny na Obr. 2.

Již $\mathrm{z}$ výše uvedeného vyplývá, že na uživatele modelu jsou kladeny poměrně menší nároky z pohledu znalostí oproti standardizovaným modelům. Nicméně pro tvůrce tento typ modelu přináší i odlišné požadavky na znalosti a dovednosti:

- ovládání daného software (pro sofistikované modely je nutno znát i pokročilé funkce, př́ip. znalost odborného nástroje pro grafiku),

- schopnost grafického cítění a kreativity při strukturovaném zobrazení reality a tvorbě vlastního modelovacího jazyka a metodiky,

- dodržení obecně používaných výrazových prostředků, $\mathrm{s}$ důrazem na přesnost a přehlednost, ale i grafickou nápaditost,

- nalezení odpovídajících vztahů realita model (často bez opory např. v již vytvořených obecných vzorech).

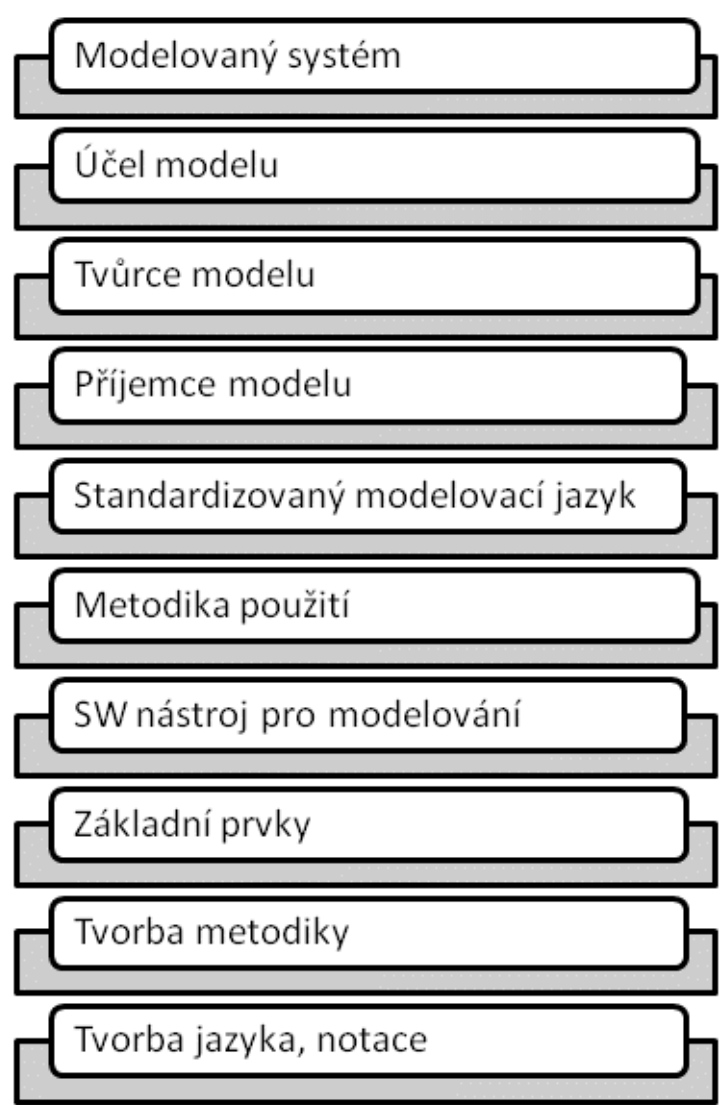

Obr. 2 - Atributy nestandardizovaného modelu

\section{Závěr}

Článek od obecného pojetí modelů $\mathrm{v}$ informatice, přes př̀dstavení jejich základních charakteristik, vede $\mathrm{k}$ návrhu vlastní klasifikace modelů a vytvoření obecné kategorie modelů: standardizované a nestandardizované. Navržené rozdělení poskytuje rámec pro uchopení podstaty a významu modelů, schopnosti tvorby i interpretace, a jejich následného použití v praxi. Klasifikace umožňuje analyzovat vlastnosti jednotlivých skupin odděleně a upozornit tak na charakteristiky, které by ze sumarizovaného pohledu byly zastíněny nebo neakcentovány. Zaměření se na určitou specifickou část odděleně pomáhá $\mathrm{v}$ rozboru této oblasti, $\mathrm{v}$ definování základních rysů, vysvětlení a objasnění skutečností. Je možné tyto kategorie modelů rozlišit a akcentovat ty charakteristiky, které mají prímý dopad na vnímání těchto modelů klíčovými skupinami uživatelů. A to jak $\mathrm{z}$ hlediska tvorby modelu, tak následného používání. Pochopením celého systému informačního modelování lze docílit zvýšení efektivity práce a dílčích kroků $\mathrm{v}$ procesu informačního modelování. 
Tyto poznatky lze využít již v prvních krocích životního cyklu modelu při rozhodování o výběru konkrétního typu modelu. Zvolením konkrétního typu modelu musí autor již ve fázi vývoje akceptovat jeho vlastnosti. Díky jasnému vymezení a popisu by nemělo docházet k rozčarování ani při užívání konkrétního modelu.

\section{Literatura}

[1] EXNAROVÁ, A., DALIHOD, M., MILDEOVÁ, S. Measuring Systems Thinking Ability. Prague 09.06.2011 - 10.06.2011. In: Efficiency and Responsibility in Education. Praha: Czech University of Life Sciences in Prague, 2011, s. 66-74. ISBN 978-80-213-2183-0.

[2] EXNAROVÁ, A. Modely $\mathrm{v}$ informatice. Praha 11.02.2010. In: Sbornik praci účastniku vědeckého semináre doktorandského studia Fakulty informatiky a statistiky VŠE v Praze. [online] Praha: Oeconomica, 2010, s. 21-28. ISBN 978-80-245-1647-9. URL: http://fis.vse.cz/studium/doktorske-studium/dendoktorandu/den-doktorandu-2010/.

[3] KŘEMEN, J. Modely a systémy. 1. vyd. Praha : Academia, ČMT, 2007. ISBN 978-80200-1477-1

[4] MILDEOVÁ, S.: Tvorba manažerských simulátorů - Vaše virtuální firma. 1. vyd. Praha : Oeconomica, 2007. 154 s. ISBN 978-80-2451286-0. (Další autoři: EXNAROVÁ, A., BEER, D., GANOCZY, E.).

[5] SENGE, P. M.: Piata disciplína manažmentu, Systémové myslenie predpoklad rozvoja organizácií, Open Windows, Bratislava, 1995, ISBN 80-85741-10-5.

Ing. Anna Exnarová

Katedra systémové analýzy

Fakulta informatiky a statistiky

Vysoká škola ekonomická v Praze

nám. W. Churchilla 4

13067 Praha 3, ČR

e-mail: anna.exnarova@vse.cz 